\title{
Color change using HSB color system of dental resin composites immersed in different common Amazon region beverages
}

\author{
Débora da COSTA E SILVA', Sanmya Beatriz da Silva Pereira TIRADENTES², Rosana Cristina Pereira \\ PARENTE $^{3}$, Maria Fulgência Costa Lima BANDEIRA ${ }^{4}$
}

\begin{abstract}
The purpose of this study is to evaluate in vitro the color stability of composite resins when exposed to beverages with high coloring contents from the Amazon region. 240 samples from four different composite brands (Natural Look, Z350, 4Seasons and Opallis) of hue $\mathrm{A} 3$ were fabricated using an acrylic matrix. The samples were stored in distilled water at $37^{\circ} \mathrm{C}$ for 24 hours. The initial color (T0) was registered using a Canon EOS Rebel XTi $10 \mathrm{mp}$ camera, and then the samples were divided into four groups (n=15): G1 (coffee), G2 (açaí juice), G3 (energetic guaraná) and G4 (control - distilled water). The samples were exposed to solutions of DES (6hs) and RE (18hs) and placed in a double boiler under constant agitation, at $37^{\circ} \mathrm{C}$ for 30 days. The samples were immersed in the coloring solutions for 15 minutes daily. After 7, 15 and 30 days, new photographic registers were made (T1, T2 and T3). The images were analyzed using Corel PHOTO-PAINT 12 software to identify the colors through the HSB system. The Kruskal-Wallis and t tests $(\mathrm{p}<0.05)$ demonstrated significant differences in color (hue, saturation and brightness). The results revealed that none of the tested composites showed color stability when exposed to coloring solutions, and that the Amazon region beverages (açaí juice and energetic guaraná) showed to be less coloring than coffee.
\end{abstract}

KEYWORDS: Composite Resins, Coloring Agents, Color Perception Tests.

\section{Alteração de cor de resinas compostas imersas em diferentes bebidas comuns da região Amazônica, utilizando o sistema de cor HSB}

\section{RESUMO}

Este estudo propôs avaliar in vitro a estabilidade de cor de alguns compósitos quando expostos a bebidas da Região Amazônica com alto teor de corante. Foram confeccionados 240 corpos de prova (CP) de quatro resinas (Natural Look, Z350, 4Seasons e Opallis) no matiz $\mathrm{A} 3$ utilizando uma matriz de acrílico. As amostras foram armazenadas em água deionizada a $37^{\circ} \mathrm{C}$ por 24 horas. A cor inicial das resinas (T0) foi registrada utilizando a máquina Canon EOS Rebel XTi 10Mp, e em seguida os CP foram divididos em 4 grupos (n=15): G1 (café), G2 (suco de açaí), G3 (guaraná energético) e G4 (controle - água destilada). Os CP foram submetidos às soluçôes DES (6hs) e RE (18hs) e colocados em banho-maria, sob constante agitação, à temperatura de $37^{\circ} \mathrm{C}$ durante 30 dias. Diariamente os corpos de prova foram imersos nas soluçóes corantes durante 15 minutos. Após 7,15 e 30 dias realizaram-se novos registros fotográficos (T1, T2 e T3). As imagens foram analisadas pelo programa Corel PHOTOPAINT 12 para a identificação das cores através do sistema HSB. O teste Kruskal-Wallis e teste t $(\mathrm{p}<0,05)$ demonstraram que a alteração de cor (matiz, saturação e brilho) indicou diferenças significantes. Foi concluído que nenhuma das resinas testadas apresentou estabilidade de cor quando em contato com as soluçôes corantes, e que as bebidas da regiáo Amazônica (suco de açaí e guaraná energético) demonstraram ser menos colorantes que o café.

PaLAVRAS-CHAVE: Resina Composta, Agentes Corantes, Teste de Percepção de Cores.

\footnotetext{
1 Faculdade de Odontologia da Universidade Federal do Amazonas - FAO - UFAM. E-mail: d_costaesilva@hotmail.com

2 Faculdade de Odontologia da Universidade Federal do Amazonas - FAO - UFAM. E-mail: sanmya_beatriz@hotmail.com

${ }^{3}$ Universidade Federal do Amazonas - UFAM. E-mail: rparente@ufam.edu.br

${ }^{4}$ Faculdade de Odontologia da Universidade Federal do Amazonas - FAO - UFAM. E-mail: fulgencia@ufam.edu.br
} 


\section{INTRODUCTION}

Currently aesthetics is of great concern to patients and professionals. Consequently, esthetics is one of the fastest growing specializations in Dentistry.

New materials and techniques have been developed to restore teeth as much as possible to resemble their natural status. Composite resin is the preferred material to achieve this end (Denehy, 2000). However, color is the most difficult individual characteristic to reproduce in restorative materials.

Until recently there was no composite material capable of satisfying both the functional necessities of a posterior restoration and the aesthetic demands of the anterior restorative correction (Denehy, 2000; Mitra et al., 2003). In order to address this need micro-hybrid and nano-filled resins appeared in the market with properties of a high degree of initial and delayed polishment, similar to that obtained by micro-filled resins, as well as excellent mechanical properties, as good as those which are commonly obtained with the hybrid composite (Mitra et al., 2003).

Although modern resins have many advantages over other aesthetics materials used until now, they are still short from providing optimal color appearance due to intrinsic and extrinsic factors (Asmussen and Hansen, 1986; Gupta et al., 2005). Impregnation from food and beverage pigments is considered the main extrinsic pigmentation factor (Asmussen, 1983).

In the use of composite resin as a restorative material, comparison to a manufacturer color scale is the most typical method of determining the right color to restore the teeth (Busato et al., 2001). It is known that color selection by the human eye is subjected to bias. This is due to specific elements, such as the observer's clinical perception and illumination both of the environment and of the object. Other elements can also modify the desired result, such as the type of composite used, its particle shape, number of resin surfaces to be used in the restorative procedure, and the dental substrate color influence.

Digital equipment used for color analysis is more precise and consistent than human vision because it can analyze color without human influence bias (Tung et al., 2002; Volpato et al., 2005). The HSB model is a digital system of color identification based on human color perception using 3 fundamental properties: Hue, a particular gradation of color (i.e. the shade or tint of a color); Saturation, vividness of hue (the degree of difference from gray) and Brightness, the percentage of brightness of the color (Leão, 2005).

The Amazon is well known for its fruit diversity. The Amazonian fruits are seeked for their high concentrations of vitamins, proteins and important mineral salts so that the consumption and exportation of Amazon fruits, such as açaí and energetic guaraná, are steadily increasing worldwide. Additionally, due to their high natural pigment content, various fruits from the region are being used and commercialized either as food coloring agents or as dental biofilm markers, such as açaí, replacing the artificial pigments (Emmi et al., 2006). On the other hand, these very same Amazonian fruits pigments can also discolor teeth and restorations (Alves et al., 2004).

This study was designed to evaluate color stability of four last generation composites exposed to Amazon region beverages with high coloring contents, such as açaí juice, energetic guaraná and coffee under different exposure times. A new methodology of color identification is also proposed.

\section{MATERIAL AND METHODS}

Four composite resins on A3 shade and four immersion solutions were used. Charts 1 and 2

Chart 1 - Classification, composition and manufacturers of the composite resins to be used

\begin{tabular}{|c|c|c|c|}
\hline Material & Classification & Composition & Manufacturer \\
\hline $\begin{array}{l}\text { Natural } \\
\text { Look }\end{array}$ & Micro-hybrid & $\begin{array}{l}\text { Bisphenol A Diglycidyllmetha- } \\
\text { crylate, Bisphenol A Diethoxy- } \\
\text { methacrylate, Triethyleneglycol } \\
\text { Dimethacrylate, Barium glass } \\
\text { silanized, Amorphous silica } \\
\text { hydrophobed. The particles } \\
\text { average size is } 0,5 \mu \mathrm{m}\end{array}$ & $\begin{array}{l}\text { DFL, Rio de } \\
\text { Janeiro, RJ, } \\
\text { Brazil }\end{array}$ \\
\hline Z350 & Nano filled & $\begin{array}{l}\text { Bis-GMA, Bis-EMA, UDMA and } \\
\text { small amounts of TEGDMA, } \\
\text { Zirconia/Silica particles with } \\
\text { a size of } 0,6 \text { to } 1,4 \text { microns } \\
\text { with primary particle size of } 5 \\
\text { to } 20 \mathrm{~nm}\end{array}$ & $\begin{array}{l}\text { 3M/ESPE, } \\
\text { Sumaré, SP, } \\
\text { Brazil }\end{array}$ \\
\hline 4 Seasons & Micro-hybrid & $\begin{array}{l}\text { Bis-GMA, Urethane } \\
\text { Dimethacrylate, Triethylene } \\
\text { Glycol Dimethacrylate, Barium } \\
\text { glass, Ytterbium trifluoride, } \\
\text { Ba-Al-fluorsilicate glass, highly } \\
\text { dispersed silicon dioxide and } \\
\text { spheroid mixed oxide. The } \\
\text { particle size is } 0,04 \text { to } 3,0 \\
\mu \mathrm{m} \text {. The mean particle size is } \\
0,6 \mu \mathrm{m} \text {. }\end{array}$ & $\begin{array}{l}\text { Ivoclar- } \\
\text { Vivadent, } \\
\text { Schaan, } \\
\text { Liechtenstein }\end{array}$ \\
\hline Opallis & Micro-hybrid & $\begin{array}{l}\text { Bis-GMA, Bis-EMA, TEGDMA, } \\
\text { silanized Barium-Aluminum } \\
\text { silicate glass and nanoparticles } \\
\text { of silicon oxide. Particles from } \\
0,02 \text { to } 3,0 \mu \mathrm{m} \text { in size with } \\
\text { average particles size of } 0,5 \\
\mu \mathrm{m} \text {. }\end{array}$ & $\begin{array}{l}\text { FGM, } \\
\text { Joinville, SC, } \\
\text { Brazil }\end{array}$ \\
\hline
\end{tabular}


Chart 2 - Beverages consumed in the Amazon region, in $\mathrm{mL}$

\begin{tabular}{ll}
\hline Beverages & $\mathrm{mL}$ \\
\hline Açaí juice (S1) & 1000 \\
Energetic guaraná juice (S2) & 1000 \\
Coffee (S3) & 1000 \\
\hline Distilled water (S4) & 1000 \\
\hline
\end{tabular}

\section{SAMPLES PRODUCTION}

Sixty samples of each material were made using a rectangular acrylic mold, fabricated with four $8 \mathrm{~mm}$ wide and $2 \mathrm{~mm}$ deep central perforations, according to ISO 4049 (International Standard Organization, 2000). The mold was placed on a glass plate enrolled with cling film. Using a resin spatula, a single increment of composite resin was inserted in each of the mold's upper surface perforations. The mold was then tightly covered by another glass plate wrapped with cling film to provide a polished surface. This last glass plate was topped by a third one so that both exerted a $1000 \mathrm{~g}$ compression force over the resin insertions. The resins were then photo-activated for 40 seconds on each surface of the samples with Optilight LD III (Gnatus, Ribeirão Preto, SP, Brazil) light source, previously checked by a radiometer, and powered to $350 \mathrm{mw} / \mathrm{cm}^{2}$ with a wave length of 460 to 490 $\mathrm{nm}$ (Reis et al., 2001). After completion of the polymerization the samples were secured with orthodontic wires and stored in individual containers which were identified (Figure1). The samples were then immersed in distilled water at $37^{\circ} \mathrm{C}$ for 24 hours after which they were photographed for the registration of their initial color.

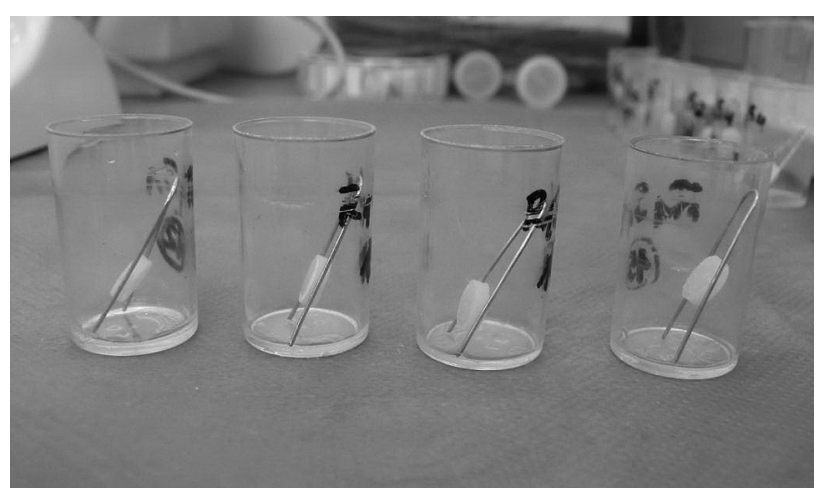

Figure 1 - Samples secured with orthodontic wires inside individual containers.

\section{PHOTOGRAPHIC REGISTRATION OF THE SAMPLE'S INITIAL COLOR}

For the photographic registration of the color of the samples a Canon high resolution camera, model EOS Rebel XTi 10 MegaPixels with a macro ring Lite MR-14EX Flash
(Canon, Ohta-ku, Tokio, Japan) was used, with the following adjustments: speed - 1/125, opening - F 9.0, ISO - 100 and flash speed $-1 / 64$. The camera was mounted on a dedicated stable support in order to standardize color registration at a focal distance of $30 \mathrm{~cm}$. A matrix with multiple perforations, each of them with the size of the sample, was completed covered with a black adhesive sheet. One of the covered perforations was used to stabilize the samples after a central 3 $\mathrm{mm} X 3 \mathrm{~mm}$ square was cut from the . adhesive sheet that was covering it. This arrangement allowed the exhibition of only the central portion of the samples to the pictures (Figure 2).

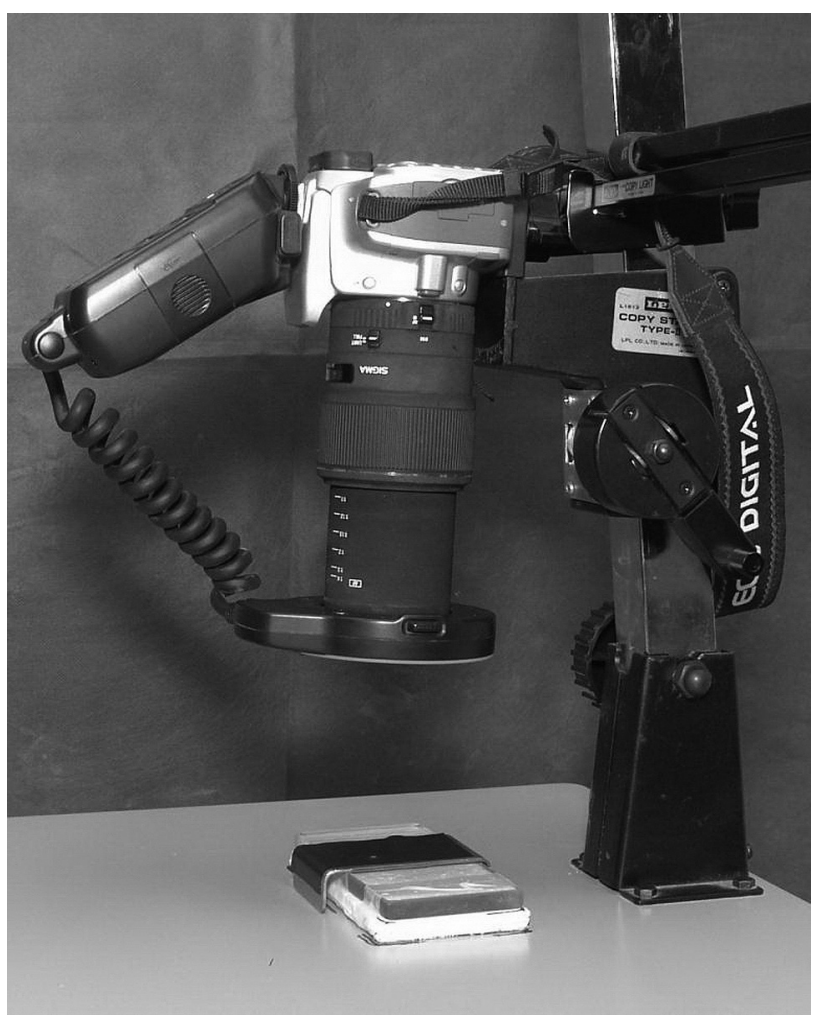

Figure 2 - Camera stabilized on the support and matrix with the sample fitted and positioned to the picture.

The samples were then divided into 4 experimental groups according to the individual immersion solutions (G1, G2, G3 and G4). Fifteen samples of each composite brand were allocated to each group.

\section{PRODUCTION OF THE COLORING SOLUTIONS}

Each immersion solution, namely, açaí juice (Brasfrut, Feira de Santana, Bahia, Brazil); energetic guaraná, prepared with powdered guaraná (Mariza, Castanhal, Pará, Brazil) and guaraná syrup (Guazil, Maués, Amazonas, Brazil); and coffee (Café Manaus, Manaus, Amazonas, Brazil), was prepared according to manufacturer's guidelines totalizing $1000 \mathrm{ml}$. The distilled water was fabricated in the laboratory of the Federal 
University of Amazonas and used as a control solution. All solutions were renewed every four days (Gupta et al., 2005). The $\mathrm{pH}$ determination, using Digimed's Ph-meter, model Dnth-2 (Digimed, Sáo Paulo, SP, Brazil), of each solution was done immediately after their preparation and at a four-day interval, after which the solutions were discarded.

\section{DEMINERALIZATION AND REMINERALIZATION (DES/RE) CYCLE OF THE SAMPLES}

The demineralization and remineralization solutions were prepared as developed by Featherstone (Featherstone et al., 1986) to simulate the cavity dynamics.

The samples were immersed in DES/RE solution inside plastic tubes and then submerged in water inside a double boiler stove at $37^{\circ} \pm 1^{\circ} \mathrm{C}$ temperature under constant agitation by a Certomat $\mathrm{MO}$ agitator (B.Braun Biotech International, Allentown, Pennsylvania, USA) at $55 \mu / \mathrm{min}$, simulating the oral cavity dynamics (Figure 3). The agitation was interrupted only while changing DES/RE solution and during the daily 15 minutes of immersion in the tested solutions. The DES/RE cycle includes an initial 18 hours immersion in the remineralization solution followed by 6 hours in demineralization solution, according to Ten Cate and Djuisters`s (1982) methodology.

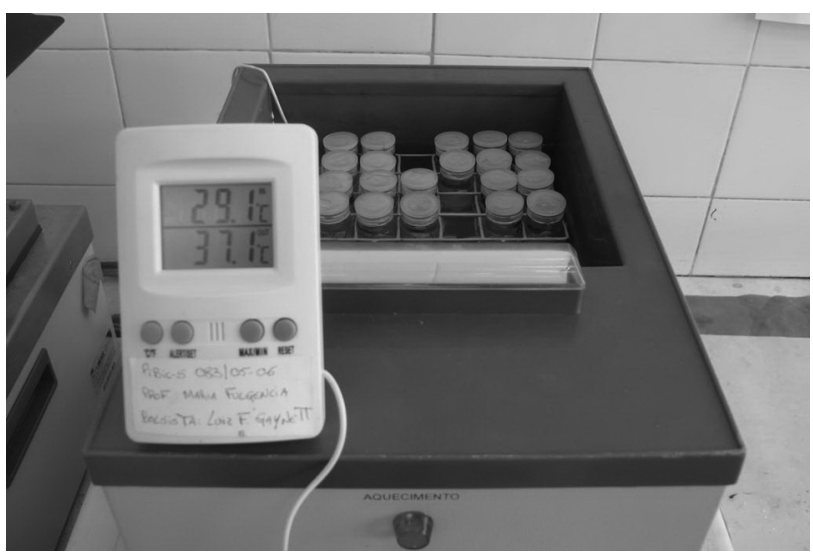

Figure 3 - Containers with the samples in DES/RE solution and inside a double boiler stove.

After every exchange of solutions (DES/RE and immersed solutions), the samples were washed twice in distilled water. At the end of each experimental period (7, 15 and 30 days), 5 samples of each group were removed from the experiment after the remineralization cycle finished and then washed and dried with absorbent paper for the photographic registration (Gupta et al., 2005).

\section{COLOR READING}

The photographic images were transferred to a computer and opened to its natural size with Corel PHOTO-PAINT 12 (Corel Corporation, Ottawa, Ontario, Canada). The identity of the colors (initial and after 7, 15 and 30 days immersion) was obtained by the PHOTO-PAINT's HSB color system which describes the color by showing its three component values (hue, saturation and brightness) in percentage numbers. These indicators determine a single color (Figure 4 and 5).

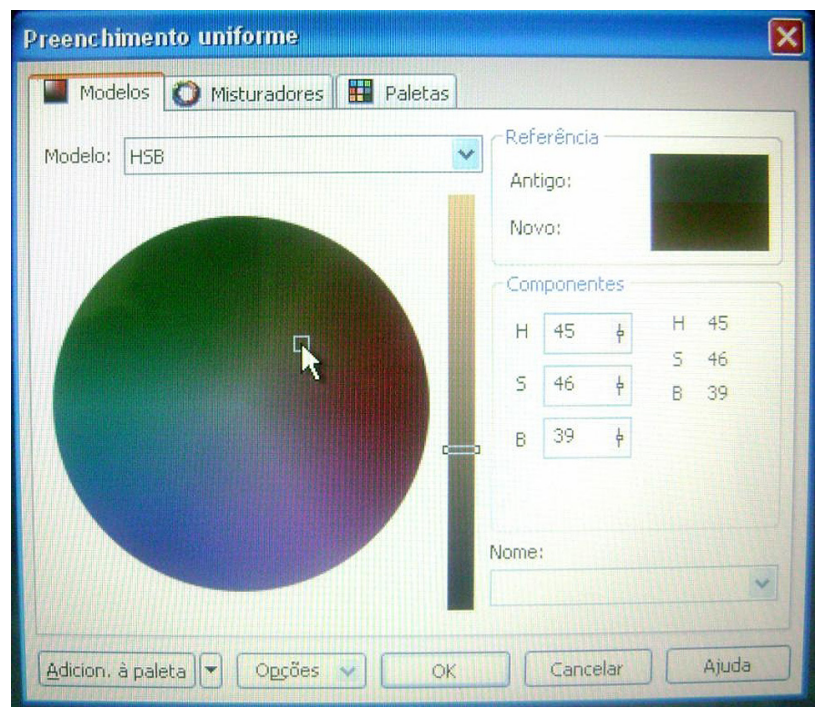

Figure 4 - HSB model of the digital system.

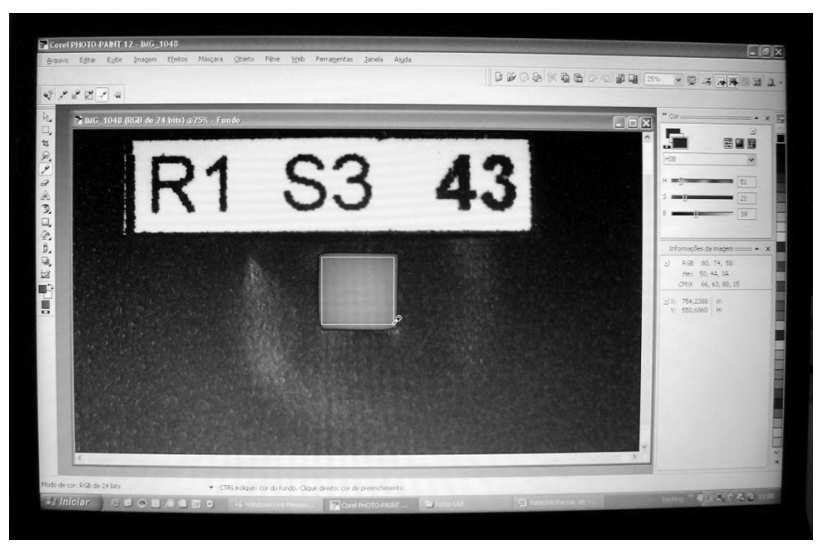

Figure 5 - Image of the sample's central portion in Corel PHOTO-PAINT 12.

\section{STATISTIC ANALYSIS}

The numeric data were analyzed by the Kruskal-Wallis and $t$ tests, considering $\mathrm{p}<0.05$. It was considered a variable the difference from the observed final values of hue, saturation and brightness of each sample to its initial values. A nonparametric test was chosen for the statistical analysis for the data observed in the experiment did not follow a normal distribution.

The results with a positive value determined a darkening of the sample, while the results with a negative value was linked to a discoloration. Both positive or negative values were considered color alteration. 


\section{RESULTS}

Data analysis was done considering the observation of the interaction between three variants: composite resin, immersed solution and time. The color alteration was determined by the analysis of the values from the HSB system. The hue property was the main variant. Saturation and brightness properties were secondary. Variation of the hue values determines that the shade or tint of the color experimented an alteraion; variation of saturation values determines a color darkening when the final value is positive, and a color discoloration when the final value is negative. Variation of brightness determines the degree of color opacity.

As the initial values of the four tested resins were compared and analyzed, variability in the hue and saturation were observed, even though they belonged to the same nominal hue (A3) determined by their manufacturers (Table 1).

Table 1 - Comparison of the resins initial values (standard)

\begin{tabular}{lcccccc}
\hline RESIN & HUE & & SATURATION & & \multicolumn{2}{c}{ BRIGHTNESS } \\
\hline Opallis & 84.4 & a & 22.6 & a & 40.6 & a \\
4 Seasons & 82.4 & a & 14.0 & b & 40.2 & a \\
Z350 & 62.6 & b & 11.2 & c & 40.2 & a \\
Natural Look & 54.6 & c & 10.8 & c & 39.2 & a \\
\hline
\end{tabular}

Distinctive letters differ from its counterparts in a level of $5 \%$ of significance

Analyzing the differences between the initial and final values of each tested resin, and having as fundamental consideration the higher value by reason of estimator (\%), the resins were classified, in increasing order of color alteration, as: Natural Look, 4 Seasons, Z350 and Opallis (Graph 1).
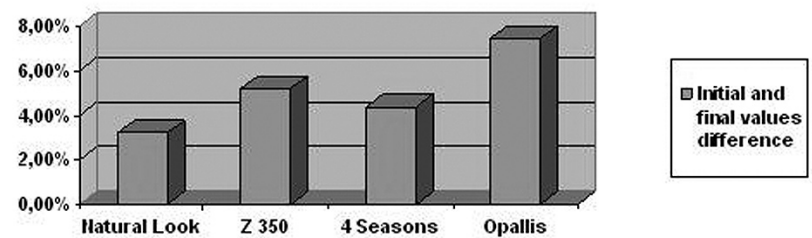

GRAPH 1 - The resins' initial and final value differences in percentage

A general higher value of color alteration was observed after 7 days and it was followed by a stabilization or slow increase in the values (Table 2).

Comparatively analyzing the results of table 3 , it was observed that all the tested solutions altered the color of the tested composites. However, with the Z350 and 4Seasons resins, the solution that caused the higher color alteration was coffee; whereas with Natural Look resin, açaí juice was the most determinant coloring solution. On the other hand, distilled water caused higher color alterations when in contact to Opallis resin.
Table 2 - Differences between experimental periods and the standard's resin values.

\begin{tabular}{lccccccc}
\hline RESIN & DAYS & HUE $(\neq)$ & $\begin{array}{c}\text { SATURATION } \\
(\neq)\end{array}$ & $\begin{array}{c}\text { BRIGHTNESS } \\
(\neq)\end{array}$ \\
\hline Natural & 7 & 3.1 & $\mathrm{a}$ & -3.05 & $\mathrm{a}$ & -1.25 & $\mathrm{a}$ \\
Look & 15 & 0.3 & $\mathrm{a}$ & -2.2 & $\mathrm{a}$ & -1.25 & $\mathrm{a}$ \\
& 30 & 1.9 & $\mathrm{a}$ & -2.45 & $\mathrm{a}$ & -1.7 & $\mathrm{a}$ \\
\hline \multirow{3}{*}{ Z 350 } & 7 & -0.8 & $\mathrm{a}$ & -0.3 & $\mathrm{a}$ & 1.3 & $\mathrm{a}$ \\
& 15 & -3.5 & $\mathrm{~b}$ & 0.05 & $\mathrm{a}$ & 0.7 & $\mathrm{a}$ \\
& 30 & -5.1 & $\mathrm{~b}$ & 1.5 & $\mathrm{~b}$ & 0.05 & $\mathrm{a}$ \\
\hline \multirow{2}{*}{ S } & 7 & -4.05 & $\mathrm{a}$ & 0.95 & $\mathrm{a}$ & -0.7 & $\mathrm{a}$ \\
Seasons & 15 & -4.65 & $\mathrm{a}$ & 1.85 & $\mathrm{a}$ & -2.4 & $\mathrm{a}$ \\
& 30 & -1.75 & $\mathrm{a}$ & 1.6 & $\mathrm{a}$ & -2.05 & $\mathrm{a}$ \\
\hline \multirow{3}{*}{ Opallis } & 7 & 8.8 & $\mathrm{a}$ & -1.15 & $\mathrm{a}$ & -1.05 & $\mathrm{a}$ \\
& 15 & 2.85 & $\mathrm{~b}$ & -0.3 & $\mathrm{a}$ & -1.5 & $\mathrm{a}$ \\
& 30 & 8.35 & $\mathrm{a}$ & -0.9 & $\mathrm{a}$ & -1.35 & $\mathrm{a}$ \\
\hline
\end{tabular}

Distinctive letters differ from its counterparts in a level of $5 \%$ of significance

Table 3 - Differences between final values and the standard values in each solution

\begin{tabular}{lccccccc}
\hline RESIN & SOLUTION & \multicolumn{2}{c}{ HUE $(\neq)$} & \multicolumn{2}{c}{ SATURATION $(\neq)$} & \multicolumn{2}{c}{ BRIGHTNESS $(\neq)$} \\
\hline \multirow{4}{*}{ Natural } & Coffee & -0.1 & $\mathrm{a}$ & 0.13 & $\mathrm{a}$ & -3.3 & $\mathrm{a}$ \\
Look & Açaí & 6.1 & $\mathrm{c}$ & -4.6 & $\mathrm{~b}$ & -1.6 & $\mathrm{ab}$ \\
& Guaraná & 0.2 & $\mathrm{ab}$ & -2.26 & $\mathrm{~b}$ & -0.6 & $\mathrm{~b}$ \\
& Water & 0.8 & $\mathrm{~b}$ & -3.5 & $\mathrm{~b}$ & 0.0 & $\mathrm{~b}$ \\
\hline \multirow{4}{*}{ Z350 } & Coffee & -7.2 & $\mathrm{a}$ & 3.8 & $\mathrm{a}$ & -3.2 & $\mathrm{a}$ \\
& Açaí & 1.26 & $\mathrm{~b}$ & -1.6 & $\mathrm{~b}$ & 1.93 & $\mathrm{~b}$ \\
& Guaraná & -6.06 & $\mathrm{a}$ & 0.2 & $\mathrm{c}$ & 1.46 & $\mathrm{~b}$ \\
& Water & -0.5 & $\mathrm{~b}$ & -0.66 & $\mathrm{bc}$ & 2.53 & $\mathrm{~b}$ \\
\hline \multirow{4}{*}{ 4Seasons } & Coffee & -13.06 & $\mathrm{a}$ & 4.13 & $\mathrm{a}$ & -4.2 & $\mathrm{a}$ \\
& Açaí & 3.26 & $\mathrm{~b}$ & 0.46 & $\mathrm{~b}$ & -0.93 & $\mathrm{~b}$ \\
& Guaraná & -5.1 & $\mathrm{c}$ & 1.06 & $\mathrm{~b}$ & -1.66 & $\mathrm{~b}$ \\
& Water & 1.0 & $\mathrm{~b}$ & 0.2 & $\mathrm{~b}$ & -0.06 & $\mathrm{~b}$ \\
\hline \multirow{4}{*}{ Opallis } & Coffee & 2.6 & $\mathrm{a}$ & -0.46 & $\mathrm{a}$ & -2.93 & $\mathrm{a}$ \\
& Açaí & 7.66 & $\mathrm{~b}$ & -0.6 & $\mathrm{a}$ & -0.86 & $\mathrm{~b}$ \\
& Guaraná & 5.5 & $\mathrm{ab}$ & -0.86 & $\mathrm{a}$ & -1.0 & $\mathrm{ab}$ \\
& Water & 10.8 & $\mathrm{c}$ & -1.2 & $\mathrm{a}$ & -0.4 & $\mathrm{~b}$ \\
\hline
\end{tabular}

Distinctive letters differ from its counterparts in a level of $5 \%$ of significance

The color alteration of all tested materials in each coloring solution can be observed in figure 6 .

\section{DISCUSSION}

Many color selection studies demonstrate a great variation in colors of tested materials compared to the same nominal color (Kim and Um, 1996; Reis et al., 2001). This finding suggests that the use of the Vita scale as a universal scale is not a precise method of color selection, since it is necessary that each manufacturer provides its own scale.

In studies of restorative material pigmentation, some resins showed a higher tendency to pigmentation than others. The coloring speed depends on each resin composition and type 


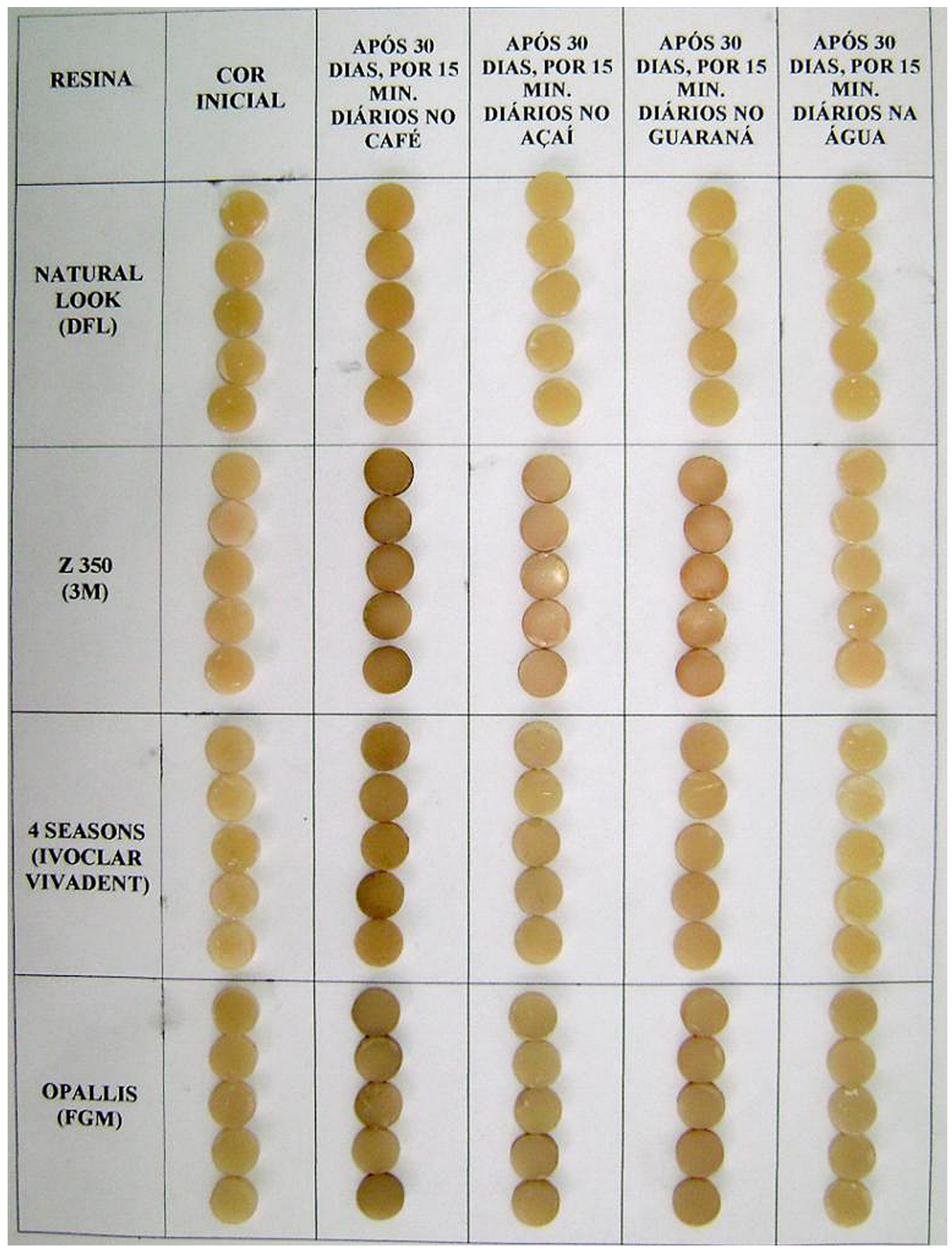

Figure 6 - Visual appearance of the initial and final samples on each tested solution. 
(Asmussem, 1983; Campos et al., 1999). The quantity of bisphenol A diglycidylether methacrylate (Bis-GMA) present in the resin composition can significantly affect the capacity of color stability (Asmussem, 1983). The higher color alteration of some materials could be also due to the presence of the ethoxylated bisphenol A dimethacrylate (Bis-EMA) molecule in its composition (Jorge, 2006). This molecule is absent in the two resins with minor color alteration (Natural Look and 4Seasons), but is found in the composition of the other two resins (Opallis and Z350) that presented the higher color alteration in this research. However, more conclusive research is needed to certify the influence of the Bis-EMA molecule on the pigmentation of composite resins.

The resin polymerization degree can also affect the color alteration. An inadequate composite resin polymerization is directly associated with color instability, which is due to easy dye and pigment diffusion through the resinous matrix (Imazato et al., 1995; Micali \& Basting, 2004).

Greatest water sorption occurs on the first 7 days after initial teeth contact with a solution, and color alteration is associated to this phenomenon (Vichi et al., 2004). This explains why composite resin pigmentation was, in many cases, strongest on the first 7 days of contact with the coloring solution, stabilizing for many weeks or slowly progressing until the end of the contact (Prado \& Porto, 2000; Teramito \& Ferreira, 2005).

A greater potential of coffee pigmentation, compared to other solutions, was observed in many studies of color stability (Campos et al., 1999; Reis et al., 2001). This fact, reported for over three decades, explains why coffee is the most frequently studied beverage. The study of Alves et al. (2004), which evaluated the color alteration of composite resins when exposed to coffee and açaí solutions, showed that coffee stained 2 to 4 times more than the açaí solution. This result is consistent with those of this study. This phenomenon can be explained by the fact that although açaí has a great amount of pigments, it also has fat particles which impede the pigment adherence to the restorative material reducing its pigmentation power. However, in this research coffee caused the greatest color alteration in two of the four tested resins, which does not necessarily prove its higher coloring power when compared to the other tested solutions.

The distilled water used as a control solution caused, with the exception of Opallis resin, a small and statistically nonsignificant resin color alteration. This result is consistent with studies that described the water as a discoloring agent (Vichi et al., 2004). The color alteration caused by the energetic guaraná solution is probably due to its composition, which has caffeine and red pigment.

The experimental solutions presented relatively stable $\mathrm{pH}$ from the first to the fourth day of research, when they were renewed. The coffee solution presented a main $\mathrm{pH}$ of 5.1; açaí 4.3; energetic guaraná 4.0; and distilled water 5.2. In 1986, Asmussen observed a smaller hardness on composite resins immersed for only a day in acetic acid, propionic and latic solution, considering that the acid solutions can soften the restorative resin and influence on superficial pigmentation susceptibility. This finding suggests that the acid $\mathrm{pH}$ of the tested solutions is one additional important factor that could influence the color alteration of the tested resins in this study.

When the color alteration is visually analyzed in figure 6 , a different conclusion from the digital color identification can be provided. This is due to the fact that the digital system identified only the central portion, where the more homogeneous portion of the sample is meant to be found. When human visual assessment is made, the unpolished edges of the samples, with their proper higher pigmentation, provide a false perception of the true central color of the object, confounding its peripheral darker color with the lighter central one.

\section{CONCLUSION}

All the tested materials underwent significant color alteration when exposed to high pigment beverages from the Amazon. The resin that presented the highest color alteration was Opallis, followed by Z350, 4Seasons and Natural Look. The color alteration was more accentuated in the first 7 days of experiment followed by a stability or a slower progression. The coffee solution caused higher color alteration on the Z350 and 4Seasons resins, whereas the most evident color alteration on the Natural Look and Opallis resin was caused, respectively, by açaí and distilled water. Further studies, however, are necessary to certify the accuracy and validate the new color reading method of the HSB system applied herein, which, nevertheless, showed consistent results when compared to many color stability studies that used currently approved methods.

\section{ACKNOWLEDGEMENTS}

This study was supported by the National Council of Technological and Scientific Development (CNPq, PIBS/036/2006). The authors are grateful to DFL, 3M/ESPE and FGM for supplying the materials tested in this study.

\section{LITERATURE CITED}

Alves, E.B.; Silva, C.M.; Araújo, J.L.N.; Rogez, H.; Silva, V.T.A.A.; Tavares, A.G.A. 2004. Estudo da Alteração de Cor de uma resina composta submetida ao manchamento com café e açaí. In: 21 a Reunião Anual da Sociedade Brasileira de Pesquisa em Odontologia/Brazilian Oral Research, Águas de Lindóia, São Paulo. Anais, 18: 234 
Asmussen, E. 1983. Factors affecting the color stability of restorative resins. Acta Odontologica Scandinavica, 41: 8-11.

Asmussen, E.; Hansen, E.K. 1986. Surface discoloration of restorative resins in relation to surface softening and oral hygiene. Scandinavian journal of dental research, 94: 174-7.

Busato, A.L.S. et al. 2001. Avaliação da estabilidade de cor inicial de diferentes resinas compostas. Revista Brasileira de Odontologia, 58(5): 348-50, Set./Out.

Campos, E.A.; Pizzocolo, L.N.; Lutti, R.N.; Porto-Neto, S.T.; Andrade, M.F. 1999. Influência de corantes sobre a translucidez de resinas compostas. Revista Ciências Odontológicas, 2(2): 1218.

Denehy, G.E. 2000. A direct approach to restore anterior teeth. American Journal of Dentistry, 13: 55-9.

Emmi, D.T.; Barroso, R.F.F.; Madruga, M.R. 2006. Análise Comparativa da eficácia de evidenciadores de placa dental à

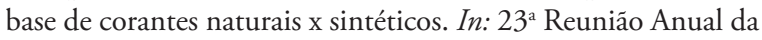
Sociedade Brasileira de Pesquisa Odontológica/Brazilian Oral Research, Atibaia, São Paulo. Anais, 20: 34.

Featherstone, J.D.B.; O’reilly, M.M.; Shariati, M.; Brugler, S. 1986. Enhancement of remineralization in vitro and in vivo. In: Leach, S. A. Factors relating to demineralization and remineralization of the teeth/IRL, Oxford, UK. p. 23-24.

Gupta, R.; Parkash, H.; Shah, N.; Jain, V. 2005. A spectrophotometric evaluation of color changes of various tooth colored veneering materials after exposure to commonly consumed beverages. Journal of Indian Prosthodontic Society, 5(2): 72-8.

Imazato, S.; Tarumi, H.; Kobayashi, K.; Hiraguri, H.; Oda, K.; Tsuchitani, Y. 1995. Relationship between the degree of conversion and internal discoloration of light-activated composite. Dental Materials Journal, 14(1): 23-30.

International Standard Organization. 2000. ISO 4049: Dentistry - polymer-based filling, restorative and luting materials. Switzerland: ISO.

Jorge, J.R.P. 2006. Estabilidade de cor de resinas compostas em função de composição e sistema de fotoativação - Avaliação através de espectroscopia de reflectância. Dissertação de Mestrado, Faculdade de Odontologia de Araraquara - UNESP, Araraquara, São Paulo. 183pp.

Kim, H.S.; Um, C.M. 1996. Color differences between resin composites and shade guides. Quintessence International, 27(8): 559-567.
Leão, A.C. 2005. Gerenciamento de Cores para Imagens Digital. Dissertação de Mestrado, Escola de Belas Artes da Universidade Federal de Minas Gerais, Belo Horizonte, Minas Gerais. $125 \mathrm{pp}$.

Micali, B.; Basting, R.T. 2004. Effectiveness of composite resin polymerization using light-emitting diodes (LEDs) or halogenbased light-curing units. Brazilian Oral Research, 18(3): 26670 .

Mitra, S.B.; Wu, D.; Holmes, B.N. 2003. An application of nanotechnology in advanced dental materials. Journal of the American Dental Association, 6: 351-8.

Paravina, R.D. 2002. Evaluation of a newly developed visual shadematching apparatus. International Journal of Prosthodontics, 15(6): 528-534.

Prado, R.R.J.; Porto, S.T.N. 2000. Estudo comparativo da estabilidade de cor de materiais estéticos. Efeito de materiais e tempo. Revista de Odontologia da UNESP, 29(1/2): 31-41.

Reis, A.; Loguercio, A.D.; Schroeder, M.; Bauer, J.R.O.; RodriguesFilho, L.E.; Busato, A.L.S. 2001. Avaliação da estabilidade de cor inicial de diferentes resinas compostas. Revista Brasileira de Odontologia, 58(5): 348-50.

Ten Cate, J.M.; Djuisters, A.M. 1982. Alternating Des/Re of artificial enamel lesions. Caries Research, 16: 201-10.

Teramito, C.L.M.; Ferreira, A.C.F. 2005. Manchamento de Restaurações Realizadas com Resinas Compostas. Revista Só Técnicas Estéticas, 2(2): 37-40.

Tung, F.F.; Goldstein, G.R.; Jang, S.; Hittelman, E. 2002. The repeatability of an intraoral dental colorimeter. Journal of Prosthetic Dentistry of St. Louis, 88(6): 585-90.

Vichi, A.; Ferrari, M.; Davidson, C.L. 2004. Color and opacity variations in three different resin-based composite products after water aging. Dental Material Copenhagen, 20(6): 530-34.

Volpato, C.A.M.; Baratieri, L.N.; Jr, S.M. 2005. Análise Instrumental da cor em Odontologia: Consideraçôes básicas. Revista Dental Press de Estética de Maringá, 2(1): 21-31.

Recebido em 29/08/2008

Aceito em 02/03/2009 